\title{
Management of soft tissue extremity degloving injuries with full-thickness grafts obtained from the avulsed flap
}

\author{
Özgür Pilancı, M.D., ${ }^{1}$ Funda Aköz Saydam, M.D., ${ }^{1}$ Karaca Başaran, M.D., ${ }^{1}$ \\ Aslı Datlı, M.D., ${ }^{1}$ Erdem Güven, M.D. ${ }^{2}$ \\ ${ }^{1}$ Department of Plastic, Reconstructive and Aesthetic Surgery, Bagcilar Research and Training Hospital, İstanbul \\ ${ }^{2}$ Department of Plastic, Reconstructive and Aesthetic Surgery, İstanbul University Faculty of Medicine, İstanbul
}

\begin{abstract}
BACKGROUND: A "degloving injury" is referred to as seperation of cutaneous tissue from the deeper structures of the body. Although many methods have been defined to reform the tissue integrity; defatting and readaptation of the avulsed flap still comprises one of the most effective methods.

METHODS: From 2000-20I2, we treated a total of nine patients with avulsed extremities with defatting and readaptation of the same flap. The fat compartment of the flaps was removed and the skin was meshed. The patients were followed-up with for an average of 12 months (range: 8-18 months).
\end{abstract}

RESULTS: Total closure of the defect and healing was achieved in seven patients. Although $30 \%$ of the total surface area of the graft was lost in one patient, and $10 \%$ in another, total epithelialization was achieved later with secondary grafting.

CONCLUSION: Defatting, meshing and readaptation of the same flap to its original site is still a valuable option for avulsion injuries because of the relative ease of the procedure, shorter operative times, and usability of the procedure by general surgeons. This technique might be particularly important in places where a reconstructive plastic surgeon is not available.

Key words: Avulsion injuries; extremity; graft.

\section{INTRODUCTION}

Degloving injuries are characterized by avulsion of the cutaneous and subcutaneous skin tissue of the extremity from more rigid deep structures as a result of trauma. Such degloving may occur on a deep fascia, muscle or bone surface. ${ }^{[1,2]}$ After damage in the musculocutaneous perforators of cutaneous and subcutaneous tissues, viability of such tissues becomes compromised.

Hidalgo divides degloving injuries into three main groups. Type $\mathrm{I}$ is an average avulsion injury, which is the most common type and is characterized by a laceration and visible

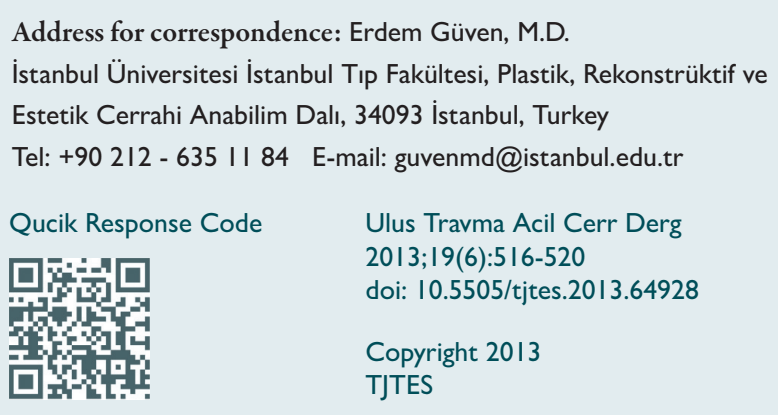

avulsed areas. Type 2 injuries are referred to as atypical avulsion injuries. At first sight, there is no serious trauma sign; however, there is actually an avulsion in a wide area. Type 3 injuries are referred to as avulsion injuries of specific areas. Such types of injuries include the plantar area and the scalp. Revascularization and replantation are required for most of these injuries. ${ }^{[3]}$

In extremity avulsion injuries, serious damage may occur in deeply located tissues, such as muscles, bones, or neurovascular structures. In these cases, the manifestation becomes more serious. If the treatment is not initiated promptly, severe complications such as wound infection, sepsis, and disseminated tissue necrosis may develop. ${ }^{[4-6]}$

Today, treatment used in cases of complex extremity injuries includes immediate debridement of the devitalized tissues and repairing the defect with the healthy soft tissue. ${ }^{[7]}$ Such principles also apply to avulsion-type injuries. ${ }^{[6]}$ However, it might not always be possible to assess the viability of the avulsed flap. ${ }^{[6,8]}$ Therefore, various procedures have been defined, including re-adaption of the flap, reconstruction with grafts, free or local flaps, revascularizations, replantations, etc. ${ }^{[1,6,9-13]}$ 
The most simple and effective treatment option is to convert the avulsed flap into a graft and re-adapt it to its original place. In this study, we present the approach of reapplying the avulsed flap after defatting as a full-thickness graft, which has been underestimated as a treatment option, but provides promising outcomes.

\section{MATERIALS AND METHODS}

A total of nine patients with degloving injuries of extremities were admitted to our clinic between 2010 and 2012. The age range was 6-33 years (mean age: 16 years). Seven patients had degloving injuries due to traffic accidents, while two patients had occupational accidents. Injury was at the upper extremity in three patients and in the lower extremity in six patients. Two patients had an accompanying trauma (Table I).

Since all patients had common-type avulsion injuries, the avulsed areas were easily visible (Figure Ia, b). Patients had an infection and tetanus prophylaxis before surgery. An effective irrigation was performed using physiological saline to minimize contamination with bacteria. Subcutaneous fat tissue was excised to obtain a full-thickness skin graft while protecting the contact between the avulsed flaps and the underlying tissue (Figure Ic). The grafts were meshed to ensure draining of hematoma and seroma. Then, the grafts were sutured to their original locations. Multiple full layers of sutures were placed on the wound in order to increase stabilization. The graft was immobilized using compressed dressing and a resting splint. Dressing was changed on the $3 r d$ postoperative day. Immobilization was maintained until the I0th postoperative day.

\section{RESULTS}

Patients were followed for 12 months on average (range: 8-18 months). Mean hospitalization period was 9 days. Almost all of the grafts were intact in seven patients. In one patient, $30 \%$ of the total surface area of the graft was lost, while $10 \%$ was lost in another. Secondary grafting was done in these patients with partial split-thickness skin grafts obtained from the lateral thigh. There was minimal graft loss in one patient, which was handled with conservative measures. A local wound infection, controlled with wound care, was noted in one patient. A hypertrophic scar developed in two patients. These patients were treated with compressed wound dressings and silicon scar gel.

\section{DISCUSSION}

In extremity avulsion injuries, it is crucial to select the treatment modality while considering the viability of the avulsed flap. Many techniques have been defined to assess the viability of the avulsed flap in literature. ${ }^{[1,8,14,15]}$ The most important issue is deciding which tissues will be protected and which tissues will be removed. ${ }^{[2]}$

Degloving injuries are most commonly caused by traumas, where musculocutaneuos perforators are ruptured but the skin cover is often intact. ${ }^{\left[{ }^{16]}\right.}$ Although at first sight, a direct adaptation of the avulsed flap at its original site seems as the most functional and cosmetic treatment, it was reported that a readapted flap may lead to a necrosis. ${ }^{[1,8]}$ The effects of various agents in increasing the viability of the avulsed flap have been studied in the literature. For example, Milcheski et al. ${ }^{[1]}$ administered intraperitoneal pentoxifylline and allopurinol in two distinct groups after adaptation of the flap at its original site in the experimental degloving rat model. Researchers determined that flap viability was higher in the test group compared to the control group. Although successful results were obtained in the experimental studies, primary repair in clinical settings often causes surgical disappointment due to venous circulation, even if the arterial flap supply was sufficient initially. ${ }^{[10,14]}$ Therefore, tests demonstrating arterial sup-

Table I. Patient characteristics

\begin{tabular}{|c|c|c|c|c|c|c|}
\hline Patient & Age & Gender & Manner of injury & Type of injury & Site & Accompanying injury \\
\hline I & 17 & Male & Occupational accident & Common & $\begin{array}{l}\text { Right hand - forearm } \\
\text { dorsal }\end{array}$ & Not available \\
\hline 2 & 33 & Female & Traffic accident & Common & Right foot dorsal & Ist finger subtotal amputation \\
\hline 3 & 6 & Male & Traffic accident & Common & Right foot dorsal & Not available \\
\hline 4 & 8 & Male & Traffic accident & Common & Left foot-ankle dorsal & Not available \\
\hline 5 & 9 & Female & Traffic accident & Common & Right foot dorsal & Not available \\
\hline 6 & 24 & Male & Traffic accident & Common & $\begin{array}{l}\text { Left hand } 3 r d-4 \text { th }-5 \text { th } \\
\text { finger dorsal }\end{array}$ & 4th finger mid- phalanx fracture \\
\hline 7 & II & Male & Traffic accident & Common & Left cruris circular & Not available \\
\hline 8 & 23 & Female & Traffic accident & Common & Right foot dorsal & Not available \\
\hline 9 & 18 & Male & Occupational accident & Common & Right forearm volar side & Not available \\
\hline
\end{tabular}



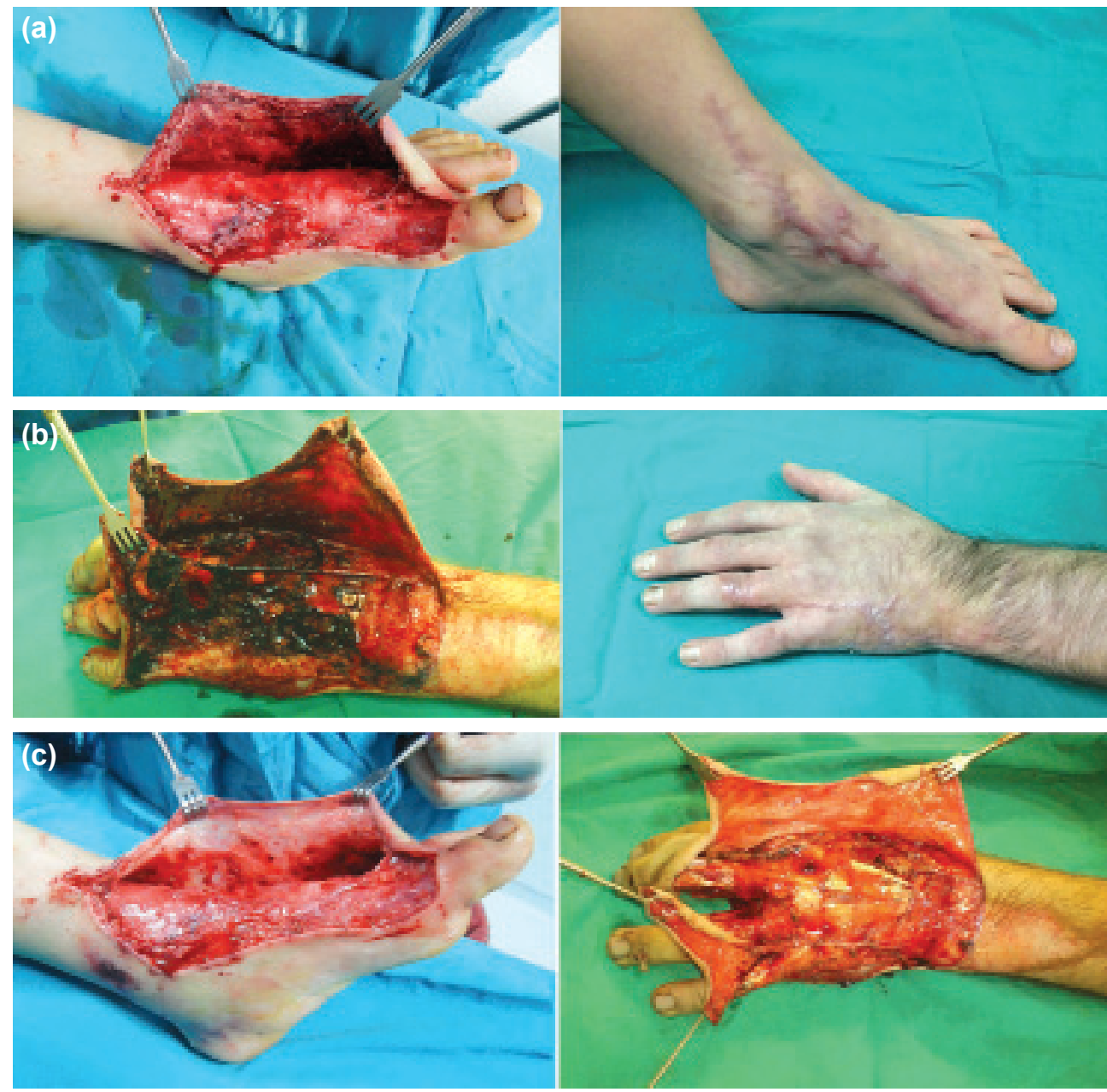

Figure 1. (a) A case of a foot avulsion. Post-operative 13th month result with defatting and adaptation of the same flap to its original site. (b) Same technique applied for a hand avulsion. Post-operative 14th month results. (c) Defatting and transformation of the flaps to full thickness grafts.

ply, such as the fluorescein test, may not be very useful for the fate of the flap in cases of degloving injuries. ${ }^{[18]}$

Microsurgical techniques have been applied to protect the avulsed flap as much as possible. Waikakul et al.,", ${ }^{[1]}$ categorized the avulsed flaps into three groups in his 32-patient series. The first 9-patient group included the patients with serious damage to the flap skin and subcutaneous tissue. In this group, the graft obtained from the flap was used for reconstruction. All patients in this group reported a graft loss of $5-35 \%$. The second group included patients with visible veins in the subcutaneous tissue who did not have venous backflow. In this group, arterializations were applied and full perfusion was achieved in 4 of 13 patients. In the third group, venous re-anastomosis was done since there was no venous backflow. Flap loss occurred in 2 of 10 patients in this group. The author stated that the group that had the graft applied recovered and became ambulatory faster despite the advantages of the microsurgery technique applied. In addition, the author reported that the flap should immediately be used as graft if perfusion cannot be achieved after arterialization and venous anastomosis. ${ }^{[10]} \mathrm{A}$ microsurgical revascularization is not always technically possible and its success rates vary; it requires advanced training and equipment, which may be considered drawbacks of the method. ${ }^{[19]}$

Flaps might be another option for covering the degloving injury defects. For example, Graf et al. ${ }^{[1]}$ treated two cases of foot degloving injuries using revascularization and dorsalis pedis flap methods, respectively. Authors reported that the foot treated with revascularization was more stable and had more physiological load distribution. Rautio et al. ${ }^{[2]}$ reported that free flaps made after degloving injuries of lower extremities may experience necrosis in time due to load-bearing. They suggested that the long-term results are more promising in these types of injuries when the free flaps are made neurosensorial. Lai et al. ${ }^{[13]}$ reported a reverse flow lateral arm adipofascial flap application in one case of an avulsion injury and achieved promising results. Elshahat et al. ${ }^{[9]}$ repaired the pediatric feet avulsion injury defects with bipedicled "delay flaps" designed from the adjacent wound area. Drawbacks of the technique were the 2-week delay and requirement for an 
additional graft at the donor site. Reconstructions with flaps can extend the time of recovery and hospitalization. Theoretically, nasocomial infections may occur due to extended treatments. ${ }^{[20]}$ In addition, reconstructions with flaps have the disadvantage of sacrificing the intact structures for wound closure. ${ }^{[21,22]}$ Thus, repair with flap should be restricted to the cases where direct bone, joint, or neurovascular structures are exposed.

Today, many surgeons suggest the early adaptation of the avulsed flap to its original site after defatting. ${ }^{[1,6,15]}$ Forming a full-thickness skin graft from the avulsed skin and the defect closure was first reported by Farmer in 1939. ${ }^{[23]}$ In the studies conducted by Kudsk and Ziv, no significant difference was observed between the full-thickness and partial-thickness grafts in terms of graft viability. ${ }^{[8,24]}$ However, full thickness grafts yield better cosmetic results. ${ }^{[16,25]}$ Jeng et al ${ }^{[6]}$ applied full-thickness grafts obtained from the flap to all 42 patients with degloving injuries at the lower extremities and reported a success rate of $91 \%$. Common-type avulsion injuries were present in $90 \%$ of the patients, while $10 \%$ of patients had atypical avulsion injuries. Graft loss occurred in 12 patients and wastreated using secondary grafts. Minimal flexion contracture at the knee was observed in 4 patients. No patients developed functional loss, and all patients were satisfied with the cosmetic outcome. Jeng et al. ${ }^{[6]}$ suggested the use of avulsed flap as a full-thickness graft as a safe and rapid repair method. Çelebioğlu et al applied the same method on their six-case series and reported success in all cases without the need for a secondary operation.

In the cases where the flap is used as the graft, success is mainly associated with an immobilization of the graft. ${ }^{[6]}$ The use of a vacuum-assisted closure (VAC) was proposed for graft immobilization to increase the viability of the graft by eliminating the problems that may occur with movement of the graft..$^{[4]}$ Wolter et al. ${ }^{[5]}$ applied artificial bilayered dermal substitute to the defect following a debridement and then repaired it using a graft. However, such methods cause an additional cost burden. Jeng et al. ${ }^{[6]}$ proposed another procedure, which includes opening drainage holes on the full-thickness grafts and fixing multiple grafts on the receptor bed. They achieved a considerably high graft survival rate using this simple method.

In our study, we achieved results similar to the literature. Seven of the nine patients recovered without any secondary operations. Partial losses were observed in two patients and were treated with a secondary partial-thickness skin grafting. None of our patients developed any late complications such as joint contractures. Immediate graft applications have shortened hospitalization time ( 9 days on average). This was an economical and a reliable method for eliminating sophisticated flap applications. In this technique, the damaged area was covered with its original tissue. Since the graft obtained is a full-thickness graft, it possesses all dermal components. This contributes to a decreased risk of contracture development.

Finally, forming a full-thickness skin graft from the flap in degloving injuries is an important advantage in terms of having fast wound coverage. Defatting decreases the infection risk since it also ensures debridement. Early repair with a graft speeds up recovery and shortens hospitalization time. Thus, the need for secondary reconstructions is prevented.

In conclusion, the avulsed flap in avulsion injuries might be immediately converted into a graft by removing its subcutaneous fat tissues. This is particulary important if there is even a slight suspicion about the viability of the avulsed flap. This method provides efficient, safe, simple, and long-term acceptable outcomes.

\section{Conflict of interest: None declared.}

\section{REFERENCES}

1. de Korte N, Dwars BJ, van der Werff JF. Degloving injury of an extremity. Is primary closure obsolete? J Trauma 2009;67:60-1. [CrossRef ]

2. Arnez ZM, Khan U, Tyler MP. Classification of soft-tissue degloving in limb trauma. J Plast Reconstr Aesthet Surg 2010;63:1865-9. [CrossRef]

3. Hidalgo DA. Lower extremity avulsion injuries. Clin Plast Surg 1986;13:701-10.

4. Dini M, Quercioli F, Mori A, Romano GF, Lee AQ, Agostini T. Vacuumassisted closure, dermal regeneration template and degloved cryopreserved skin as useful tools in subtotal degloving of the lower limb. Injury 2012;43:957-9. [CrossRef ]

5. Wolter TP, Noah EM, Pallua N. The use of Integra in an upper extremity avulsion injury. Br J Plast Surg. 2005;58:416-8. [CrossRef ]

6. Jeng SF, Wei FC. Technical refinement in the management of circumferentially avulsed skin of the leg. Plast Reconstr Surg 1997;100:1434-41.

7. Naique SB, Pearse M, Nanchahal J. Management of severe open tibial fractures: the need for combined orthopaedic and plastic surgical treatment in specialist centres. J Bone Joint Surg Br 2006;88:351-7. [CrossRef]

8. Kudsk KA, Sheldon GF, Walton RL. Degloving injuries of the extremities and torso. J Trauma 1981;21:835-9. [CrossRef ]

9. Elshahat A. Management of complex avulsion injuries of the dorsum of the foot and ankle in pediatric patients by using local delayed flaps and skin grafts. Eplasty 2010;10:64.

10. Waikakul S. Revascularization of degloving injuries of the limbs. Injury 1997;28:271-4. [CrossRef ]

11. Graf P, Kalpen A, Biemer E. Revascularisation versus reconstruction of degloving injuries of the heel: case report. Microsurgery 1995;16:149-54.

12. Rautio J. Resurfacing and sensory recovery of the sole. Clin Plast Surg 1991;18:615-26.

13. Lai CS, Tsai CC, Liao KB, Lin SD. The reverse lateral arm adipofascial flap for elbow coverage. Ann Plast Surg 1997;39:196-200. [CrossRef ]

14. McGrouther DA, Sully L. Degloving injuries of the limbs: long-term review and management based on whole-body fluorescence. Br J Plast Surg 1980;33:9-24. [CrossRef]

15. Çelebioğlu S, Keser A, Arifoğlu K, Ortak T, Koçer U. Ekstremite avülsiyon yaralanmalarında klinik deneyimlerimiz. Acta Orthop Traumatol Turc 1997;31:141-4. 
16. Nogueira A, Martínez MJ, Arriaga MJ, Pérez A, Tévar aF. Delayed fullthickness autografting of cryopreserved avulsed skin in degloving injuries of the extremities. Plast Reconstr Surg 2001;107:1009-13. [CrossRef ]

17. Milcheski DA, Nakamoto HA, Tuma P Jr, Nóbrega L, Ferreira MC. Experimental model of degloving injury in rats: effect of allopurinol and pentoxifylline in improving viability of avulsed flaps. Ann Plast Surg 2013;70:366-9.

18. Huygen RE, Hovius SE, van der Meulen JC. Treatment of extensive avulsions of the skin and soft tissues of the extremities. [Article in Dutch] Ned Tijdschr Geneeskd 1986;130:1836-40. [Abstarct]

19. Suliman MT. Distally based adipofascial flaps for dorsal foot and ankle soft tissue defects. J Foot Ankle Surg 2007;46:464-9. [CrossRef ]

20. Park SH, Silva M, Bahk WJ, McKellop H, Lieberman JR. Effect of re- peated irrigation and debridement on fracture healing in an animal model. J Orthop Res 2002;20:1197-204. [CrossRef]

21. Lee YH, Rah SK, Choi SJ, Chung MS, Baek GH. Distally based lateral supramalleolar adipofascial flap for reconstruction of the dorsum of the foot and ankle. Plast Reconstr Surg 2004;114:1478-85. [CrossRef]

22. Uysal AC, Alagöz MS, Sensöz O. Distally based lateral supramalleolar adipofascial flap. Plast Reconstr Surg 2006;117:685-6. [CrossRef ]

23. Farmer AW. Treatment of avulsed skin flaps. Ann Surg 1939;110:951-9.

24. Ziv I, Zeligowski A, Mosheiff R, Lowe J, Wexler MR, Segal D. Splitthickness skin excision in severe open fractures. J Bone Joint Surg Br 1988;70:23-6.

25. Goris RJ, Nicolai JP. A simple method of taking skin grafts from the avulsed flap in degloving injuries. Br J Plast Surg 1982;35:58-9. [CrossRef ]

\section{KLINIKK ÇALIŞMA - ÖZET}

\section{Yumuşak doku ekstremite avülzyon (degloving) yaralanmalarının avülze flepten elde edilmiş tam kalınlıklı deri grefti ile onarımı Dr. Özgür Pilancı, ${ }^{1}$ Dr. Funda Aköz Saydam, ${ }^{1}$ Dr. Karaca Basaran, ${ }^{1}$ Dr. Aslı Datı, ${ }^{1}$ Dr. Erdem Güven ${ }^{2}$}

${ }^{1}$ Bağcılar Egitim ve Araştırma Hastanesi, Plastik Rekonstrüktif ve Estetik Cerrahi Kliniği, İstanbul

${ }^{2}$ İstanbul Üniversitesi İstanbul Tıp Fakültesi, Plastik Rekonstrüktif ve Estetik Cerrahi Anabilim Dalı, İstanbul

AMAÇ: Deri ve subkütan dokunun muskulofasyal tabaka sağlam kalacak şekilde derindeki yapılardan ayrılmasına avülzyon (degloving) yaralanması denir. Doku bütünlüğünün yeniden sağlanması için birçok yöntem tanımlanmış olsa da, avülze flebin yağ dokudan arındırılarak yeniden yerine adaptasyonu hala en etkili yöntemlerden birisidir.

GEREÇ VE YÖNTEM: Kliniğimizde 2000-2012 yılları arasında ekstremite avülzyon yaralanması mevcut dokuz hastada avülze flebi yağ dokudan arındırdık. Grefte yamalar açarak yeniden yerine adapte ettik. Hastalar ortalama I2 ay takip edildi (dağıım, 8-I8 ay).

BULGULAR: Yedi hastada tamama yakın iyileşme elde ettik. Bir hastada greftin \%30'unda, diğerinde ise \%।0'a yakın kayıp gözlemledik. Fakat bu hastalar sekonder greftlemelerle epitelizasyon sağlanarak sorunsuz tedavi edildi.

TARTIŞMA: Avülzyon yaralanmalarında yağ doku uzaklaştıılarak, greftin yama ile eski yerine adaptasyonu hala değerini korumaktadır. Bunun başlıca sebebi, yöntemin genel cerrahlar tarafından da kısa sürede kolaylıkla uygulanabilir olmasıdır. Bu da plastik cerrahlara ulaşmanın zor olduğu durumlarda önem arz edebilir.

Anahtar sözcükler: Avülzyon yaralanmaları; ekstremite; greft.

Ulus Travma Acil Cerr Derg 2013;19(6):516-520 doi: 10.5505/tjtes.2013.64928 